\title{
Effects of White Mulberry (Morus alba) Leaves on Blood Vessel Reactivity in Hyperchloesterolemic Rats
}

\author{
Sang-Hoon Choi and Kwan Ha Park* \\ Department of Aquatic Life Medicine, College of Ocean Science \& Technology, \\ Kunsan National University, Gunsan City, Jeonbuk, Korea \\ (Received December 24, 2012/Revised May 8, 2013/Accepted September 4, 2013)
}

\begin{abstract}
In atherosclerosis, blood vessels become sensitive to vessel-constricting agents leading to reduced control in the event of abrupt blood pressure changes. Mulberry trees (Morus alba L., MA) have been claimed to contain various bioactive principles that could possibly prevent atherosclerosis development caused by high cholesterol consumption. In order to examine whether MA feeding can prevent the sensitization of blood vessels, MA leaves were fed to rats for 8 weeks and pressor responses to vasoconstricting agents were assessed. Animals were pithed before blood pressure assessments to eliminate reflex compensation in vessel responses. Feeding diets containing high levels of cholesterol led to potentiated pressor responses to sympathetic nerve stimulation, or to injection of norepinephrine, phenylephrine, angiotensin II and vasopressin in pithed rats. These potentiated pressor responses were prevented in rats fed MA leaf-containing diets at 2 or $10 \%$ levels. It was also examined in anesthetized non-pithed rats whether similar cholestrol-related sensitization and MA prevention could be observed. However, high cholesterol-induced sensitization in pressor responses were not observed, suggesting that destruction of central cardiovascular control by pithing must have revealed the sensitization responses. It was concluded that MA leaves seem to be active in preventing abnormal blood vessel reactivity caused by hypercholesterolemia.
\end{abstract}

Key words: mulberry tree leaves, pithed rats, pressor agents

\section{Introduction}

White mulberry trees (Morus alba L.) is a ubiquitous plant species found all around the world ${ }^{1)}$, but more frequently in the eastern Asian countries and the Europe ${ }^{2)}$. The trees have also been cultivated mostly for the purpose of silk worm feeding and also for ruminant foilage ${ }^{3)}$. In our country recently, however, their leaves and fruits have been receiving increasing attention more as human health foods ${ }^{4}$. These folk medicinal plants are claimed to have various beneficial pharmacological effects: the trees are considered antidiabetic, anti-hypertensive, anti-inflammatory, anti-rheumatic, diuretic, anti-carcinogenic, anti-ageing and anti-oxidative among others ${ }^{5)}$. Important activities demonstrated with more convincing experimental evidence includes antimicrobial activity $^{6,7)}$, antioxidant activity ${ }^{8,9)}$, anti-atherosclerotic effects ${ }^{10,11)}$, diabetes prevention effects ${ }^{12,13)}$, and cancer preventive effects $^{9,14)}$.

\footnotetext{
*Correspondence to: Kwan Ha Park, Department of Aquatic Life Medicine, College of Ocean Science \& Technology, Kunsan National University, Gunsan City, Jeonbuk, Korea

Tel: 82-63-469-1885, Fax: 82-63-464-4806

E-mail: khpark@kunsan.ac.kr
}

In the pre-atherosclerotic stage, where macroscopic atherosclerotic lesions are yet absent, increased blood vessel responses to vascular constricting drugs were reported in high-cholesterol diet-fed atherosclerotic animals ${ }^{15,16,17)}$. Such changes imply that the altered blood vessel sensitivity could be responsible for secondary disease symptoms such as hypertension and stroke.

In this study it was examined whether long term feeding of MA leaves can prevent the abnormal responses to vasocontricting agents in hypercholesterolemic animals. Because of the recent increases in consumption of MA components as health foods and the lack of information on long-term in vivo cardiovascular effects of these herbal substances, it was attempted to examine the effects of MA on blood vessel responses in rats fed high level cholesterol.

\section{Materials and Methods}

\section{Test substance and reagents}

Leaves of M. alba was collected from a herbal market in Gunsan City, dried in the shade, and finely pulverized for diet preparation. Analytical kits for total cholesterol was purchased from Sigma (St. Louis, MO, USA). All other reagents were obtained from Sigma, if not specified otherwise. 


\section{Animal treatments}

Specific pathogen-free Sprague-Dawley male rats (4 week old) were purchased from Damul Science (Daejon, Korea) and acclimated for one week in the laboratory. The animals were maintained in an air-filtered rodent cabinet maintained at $23 \pm 1^{\circ} \mathrm{C}$ and $55 \pm 5 \%$ relative humidity. The cabinet was illuminated with a $12 \mathrm{~h}$-light/dark cycle. Rats were supplied with diets and tap water ad libitum.

Rats were fast for $12 \mathrm{hr}$ before surgery for blood pressure monitoring. Blood was taken for cholesterol analysis with a heparin-rinsed syringe from the arterial cannula implanted for blood pressure measurement purposes Plasma was obtained by centrifugation for $30 \mathrm{~min}$ at $3,600 \times \mathrm{g}$ and $3^{\circ} \mathrm{C}$.

\section{Experimental diets}

The control diet was modified from AIN-93 ${ }^{18)}$ as containing (in $\mathrm{g} / \mathrm{kg}$ feed) corn starch 415.7 , dextrin 155 , casein 140, powdered cellulose 100, soybean oil 40, AIN-93Mmineral mix 35, AIN-93-vitamin mix 10, choline bitartrate 2.5, and L-cystine 1.8. In high cholesterol diet, equal part of soybean oil was replaced with cholesterol $10 \mathrm{~g}$ and sodium cholate $5 \mathrm{~g}$. For MA supplementation, cellulose was replaced with an equal quantity of pulverized MA leaves (Table 1). This supplementation was based on the fact that the highest component is crude fiber in full-grown MA leaves ${ }^{19}$. Prepared diets were supplied to respective groups for 8 weeks. Each group was composed of 12 rats.

\section{Surgery for anesthetized and pithed rat preparations}

To monitor blood pressure and heart rate changes in anesthetized rats, pentobarbital-Na was administered into the peritoneal cavity at $60 \mathrm{mg} / \mathrm{kg}$ doses. Femoral artery and vein were catheterized with PE-50 polyethylene cannula respectively for blood pressure monitoring and intravenous drug injections.
To prepare pithed rats, light anesthesia was induced using ether, and the trachea was immediately cannulated with a tracheal tubing for artificial respiration. The rats were then pithed with a copper pithing rod (diameter $2.2 \mathrm{~mm}, 23 \mathrm{~cm}$ long) through the right orbit pushing down through the spinal column as described by Shipley and Tilden ${ }^{20}$. During this pithing process, the brain and spinal column structures were maximally destroyed. The right common carotid artery and jugular vein were respectively catheterized with PE-50 polyethylene cannula for cardiovascular change measurement and intravenous administration of drugs. Using a rodent respirator (Harvard Apparatus, Holliston, MA, USA), rats were artificially ventilated at 60 strokes/min with room air at $1 \mathrm{ml} / 100 \mathrm{~g}$ body weight rate. The body temperature was sustained at $37^{\circ} \mathrm{C}$ with a heating table composed of water bath and stainless plate. Blood pressure and heart rate were recorded with a pressure transducer and cardiotachometer and the signals were recorded in a physiography (Polygraph 4006, Letica, Barcelona, Spain). Tests were performed in the following order: electrical stimulation, norepinephrine, phenylephrine, angiotensin II and vasopressin. All doss were administered in a cumulative manner when effects of the previous dose reached peak responses. New drugs were tested when effects of a previous drug disappeared.

\section{Statistical analysis}

Data were expressed as mean \pm S.D. Statistical significance was tested using one-way analysis of variance followed by Newman-Keul's t-test. Significance level was set as p-values $<0.05$.

\section{Results and Discussion}

\section{Basic parameters}

Basal data on rats fed different experimental diets are

Table 1. Composition of experimental diets ( $\mathrm{g} / \mathrm{kg}$ feed)

\begin{tabular}{|c|c|c|c|c|c|c|}
\hline Components & Control & High cholesterol & $2 \% \mathrm{MA}+$ cholesterol & $10 \% \mathrm{MA}+$ cholesterol & $2 \% \mathrm{MA}$ & $10 \% \mathrm{MA}$ \\
\hline Corn starch & 415.7 & 415.7 & 415.7 & 415.7 & 415.7 & 415.7 \\
\hline Dextrin & 155 & 155 & 155 & 155 & 155 & 155 \\
\hline Casein & 140 & 140 & 140 & 140 & 140 & 140 \\
\hline Cellulose & 100 & 100 & 20 & - & 80 & - \\
\hline Soybean oil & 40 & 25 & 25 & 25 & 40 & 40 \\
\hline AIN--93M-mineral mix & 35 & 35 & 35 & 35 & 35 & 35 \\
\hline AIN-93-vitamin mix & 10 & 10 & 10 & 10 & 10 & 10 \\
\hline Choline bitartrate & 2.5 & 2.5 & 2.5 & 2.5 & 2.5 & 2.5 \\
\hline L-Ccystine & 1.8 & 1.0 & 1.0 & 1.0 & 1.0 & 1.0 \\
\hline Cholesterol/sodium cholate & - & $10 / 5$ & $10 / 5$ & $10 / 5$ & - & - \\
\hline Morus alba powder & - & - & 20 & 100 & 20 & 100 \\
\hline
\end{tabular}

All components were obtained from Sigma Co. except mineral mix and vitamin mix, both of which were from Harlan Tek Lad (Kent, WA, USA). 
Table 2. Basal parameters in rats fed with $M$. alba leaves for 8 weeks

\begin{tabular}{|c|c|c|c|c|c|c|c|c|}
\hline \multirow[b]{2}{*}{ Group } & \multirow{2}{*}{\multicolumn{2}{|c|}{$\begin{array}{l}\text { Body weight, } \mathrm{g} \\
\quad(\mathrm{n}=10)\end{array}$}} & \multirow{3}{*}{ 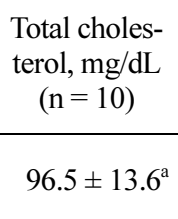 } & \multirow{3}{*}{$\begin{array}{c}\begin{array}{c}\text { Mean feed } \\
\text { intake, g/day } \\
(\mathrm{n}=10)\end{array} \\
23.4 \pm 4.4\end{array}$} & \multicolumn{2}{|c|}{ Anesthetized $(\mathrm{n}=5)$} & \multicolumn{2}{|c|}{ Pithed $(n=10)$} \\
\hline & & & & & $\begin{array}{l}\text { mean AP } \\
(\mathrm{mmHg})\end{array}$ & $\begin{array}{c}\mathrm{HR} \\
\text { (bpm) }\end{array}$ & $\begin{array}{l}\text { mean AP } \\
(\mathrm{mmHg})\end{array}$ & $\begin{array}{l}\mathrm{HR} \\
(\mathrm{bpm})\end{array}$ \\
\hline Control & $\begin{array}{l}\text { start } \\
\text { final }\end{array}$ & $\begin{array}{l}116.2 \pm 8.4 \\
363.7 \pm 21.6\end{array}$ & & & $129.3 \pm 8.8$ & $452.5 \pm 12.4$ & $62.4 \pm 5.6$ & $287 \pm 25.7$ \\
\hline High cholesterol & $\begin{array}{l}\text { start } \\
\text { final }\end{array}$ & $\begin{array}{l}126.8 \pm 7.7 \mathrm{a} \\
332.7 \pm 32.6\end{array}$ & $153.6 \pm 34.6^{\mathrm{b}}$ & $20.7 \pm 5.5$ & $118 \pm 6.7$ & $487.7 \pm 22.1$ & $63.1 \pm 6.0$ & $253 \pm 34.0$ \\
\hline $2 \% \mathrm{MA}+$ cholesterol & $\begin{array}{l}\text { start } \\
\text { final }\end{array}$ & $\begin{array}{l}129.6 \pm 6.1 \\
347.9 \pm 20.6\end{array}$ & $145.3 \pm 21.2^{\mathrm{b}}$ & $25.2 \pm 5.0$ & $122 \pm 3.5$ & $476.3 \pm 17.9$ & $60.9 \pm 8.1$ & $248 \pm 25.3$ \\
\hline $10 \% \mathrm{MA}+$ cholesterol & $\begin{array}{l}\text { start } \\
\text { final }\end{array}$ & $\begin{array}{l}124.4 \pm 8.2 \\
330.1 \pm 42.0\end{array}$ & $127.6 \pm 22.8^{b}$ & $21.9 \pm 4.7$ & $124 \pm 2.1$ & $421.7 \pm 32.6$ & $58.4 \pm 6.6$ & $256 \pm 14.7$ \\
\hline $2 \% \mathrm{MA}$ & $\begin{array}{l}\text { start } \\
\text { final }\end{array}$ & $\begin{array}{l}116.8 \pm 8.0 \\
348.9 \pm 19.9\end{array}$ & $102.4 \pm 8.3^{\mathrm{a}}$ & $24.4 \pm 6.3$ & $119 \pm 2.8$ & $459.4 \pm 22.3$ & $58.6 \pm 8.7$ & $278 \pm 22.0$ \\
\hline $10 \% \mathrm{MA}$ & $\begin{array}{l}\text { start } \\
\text { final }\end{array}$ & $\begin{array}{l}124.4 \pm 7.6 \\
342.0 \pm 48.0\end{array}$ & $73.1 \pm 12.7^{\mathrm{c}}$ & $27.0 \pm 6.2$ & $121 \pm 5.8$ & $434.8 \pm 34.9$ & $60.5 \pm 4.2$ & $269 \pm 32.3$ \\
\hline
\end{tabular}

Mean AP: arterial pressure calculated from 1/3 systolic $+2 / 3$ diastolic arterial pressure; Mean feed data were estaimated trice at 0,4 and 8 weeks; Different superscripts to data denote statistical differences at $\mathrm{p}<0.05$ with Newman-Keul's t-test; In other parameters in the table, no statistical differences were observed among groups (no superscripts).

shown in Table 2. There was a significant elevation in serum total cholesterol levels in high cholesterol diet-fed rats. This elevated cholesterol was not influenced by MA feeding either at 2 or $10 \%$ concentration level. However, a weak lowering tendency dependent on MA contents was noticed in high cholesterol-fed rats. Apart from the failure to counteract cholesterol elevation, $\mathrm{MA}$ alone at $10 \%$ significantly lowered basal cholesterol concentrations. There were not any significant differences in other parameters examined: body weight changes and cardiovascular parameters were similar among treatment groups.

Although blood pressure and heart rates were not different among dissimilar diet groups, lower basal values were apparent in pithed rats compared with anesthetized animals. Pithed rats are surgically prepared by eliminating most part of the central nervous system, and thus tonic stimulation of central sympathetic drives are dismissed resulting in lower blood pressure and heart rate ${ }^{21}$. This animal model is uniquely useful in examining peripheral cardiovascular system responses in the absence of central control. As expected after pithing, lower basal blood pressure and slow heart rate were observed.

\section{Blood pressure responses to phenylephrine in an- esthetized rats}

It was reported that blood vessels isolated from hycholesterolemic animals react in a sensitive manner to vasoconstricting agents ${ }^{22,23)}$.

To estimate the effect of MA on sensitivity to vessel-constricting agent, pressor responses were induced by injecting
Table 3. Effects of M. alba leaf feeding on pressor responses elicited by phenylephrine in anesthetized rats

\begin{tabular}{cccc}
\hline \multirow{2}{*}{ Group } & \multicolumn{3}{c}{$\begin{array}{c}\text { Pressor response to phenylephrine } \\
\text { (increase in mmHg) }\end{array}$} \\
& $1 \mu \mathrm{g} / \mathrm{kg}$ & $3 \mu \mathrm{g} / \mathrm{kg}$ & $10 \mu \mathrm{g} / \mathrm{kg}$ \\
\hline Control & $5.01 \pm 1.21^{\mathrm{a}}$ & $13.89 \pm 1.81^{\mathrm{a}}$ & $24.22 \pm 5.44^{\mathrm{a}}$ \\
Cholesterol & $4.16 \pm 0.83^{\mathrm{a}}$ & $8.32 \pm 1.34^{\mathrm{b}}$ & $23.05 \pm 3.28^{\mathrm{a}}$ \\
$\mathrm{MA}+$ cholesterol & $5.21 \pm 0.68^{\mathrm{a}}$ & $11.67 \pm 0.92^{\mathrm{c}}$ & $17.34 \pm 5.10^{\mathrm{a}}$ \\
\hline $\mathrm{n}=5$ & \\
Different superscripts to denote statistical significance at $\mathrm{p}<0.05$ \\
with Newman-Keul's t-test. \\
Cholesterol: high cholesterol diet; MA: M. alba $2 \%$ diet
\end{tabular}

phenylephrine to rats. Pressor responses to phenyephrine were not altered by high cholesterol diet, nor did MA feeding influence the response in anesthetized rats (Table 3).

Phenylephrine elevates blood pressure (pressor responses) acting directly on resistance blood vessels via adrenergic alpha receptors ${ }^{24)}$. Despite the expectation of potentiated pressor responses to phenylephrine in hypercholesterolemic rats, potentiated effects were not observed in anesthetized rats. Two possible speculations are considered: (1) anesthetized rats have high resting blood pressure, i.e., $118-129 \mathrm{~mm} \mathrm{Hg}$ resting level (refer to Table 2, in pithed rats $58-63 \mathrm{~mm} \mathrm{Hg}$ for comparison), leaving less margin for additional elevations to phenylephrine; (2) reflex control of the systemic blood pressure is in action interfering the disclosure of potentiated responses. Both of these influences could be removed by destroying central nervous systems of the animal by pithing ${ }^{25)}$. 


\section{Blood pressure responsiveness to electrical stimu- lation}

As stated above, there was no potentiated pressor reactivity to phenylephrine injection in anesthetized, hypercholesterolemic rats (refer to Table 3). In the next study, pressor responses were examined after pithing the animal. Pressor responses were induced by stimulating sympathetic neurons at the spinal cord. By stimulating electrically the thoraco-lumbar neuronal outflows at the spinal cord, cardiovascular activity to activated sympathetic systems can be artificially mimicked ${ }^{26)}$. The model has been employed in testing responses of drugs preferentially at the peripheral resistance vessels. For this important reason, the model has long been in use for systemic cardiovascular actions ${ }^{27,28)}$.

Pithed rats exhibit cardiovascular responses originating from only peripheral sites. In this animal model, neurons in the thoraco-lumbar region were electrically stimulated to produce excitatory sympathetic responses. As shown in Fig. 1 , feeding of high cholesterol-containing diets significantly potentiated pressor responses induced by electrical stimulation. The potentiation in blood pressure response was almost completely blocked in $M$. alba-fed animals both 2 and $10 \%$ levels. MA feeding itself did not influence the pressor responses. Heart rate responses were also recorded, but there was no difference in the heart rate responses among different feeding groups (data not shown).

Stimulation of the sympathetic system leads to pressor response production by endogenous norepinephrine ${ }^{26)}$, in contrast to exogenously administered phenylephrine, for example. Therefore, the potentiation of pressor responses by high cholesterol diet will be interpreted either as facilitation

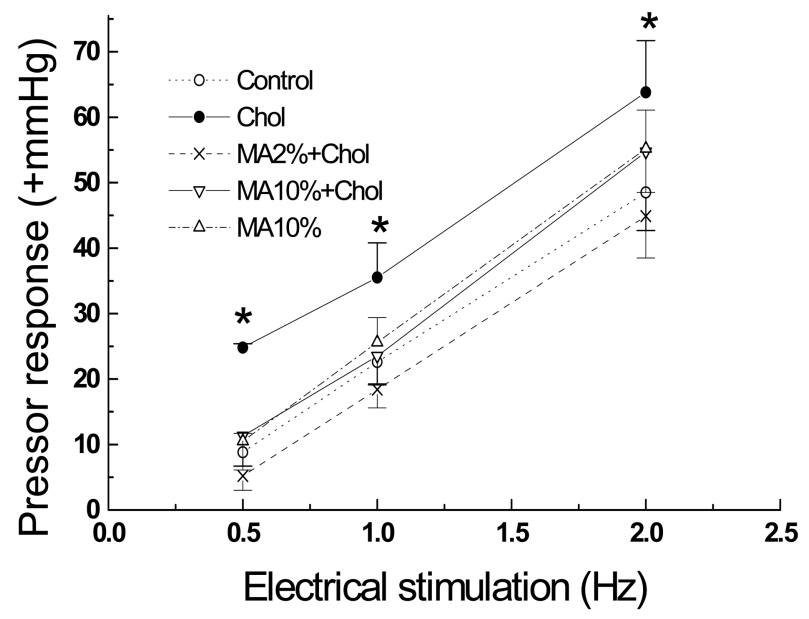

Fig. 1. Effects of M. alba leaf feeding on pressor responses elicited by sympathetic nerve stimulation in pithed rats $\mathrm{n}=5$

*Significant difference at $\mathrm{p}<0.05$ with Newman-Keul's t-test. Chol: high cholesterol diet; MA, M. alba diet of norepinephrine release or sensitization of resistance vessels. There have been evidence that vessel sensitivity is linked to increased sympathetic drive under hypercholesterolemic conditions ${ }^{29,30)}$. Others proposed increased sensitivity of the vessel itself ${ }^{21,22)}$.

Whatever the cause for the cholesterol feeding-related potentiating was, MA could effectively prevent the potentiations. Participation of central nervous system in cardiovascular status in vivo will certainly interfere with the conclusion.

\section{Blood pressure responses to pressor agents of different action mechanisms}

Cholesterol feeding significantly potentiated electrical stimulation-induced pressor responses, and the potentiation was reversed by MA feeding (Fig. 1). The results pose a question whether the potentiation and reversal holds true for other pressor agents of different action mechanisms. The results are shown in Fig. 2. Norepinephrine, when injected into the venous, produced pressor responses, the responses were diminished by MA. This observation confirms that the reversal by MA identified in the electrically stimulation must have exerted its effects directly on the blood vessel level, rather than on norepinephrine release.

Phenylephrine-induced responses were also potentiated in cholesterolemic rats and were diminished by MA. This is in direct contrast to that in anesthetized rats where neither potentiation to phenylephrine nor reversal by MA was observed. Quite similarly, antiotensin II- and vasopressioninduced responses, both are known to stimulate respective receptors ${ }^{31,32.33)}$, were also prevented by MA. The results collectively indicate MA protects the sensitization of resistance blood vessels in rats fed high cholesterol diets for a long period.

As the mechanism for correcting blood vessel responsiveness by MA feeding, there seems to complex mechnisms independent of simple lowering of blood cholesterol ${ }^{11,34)}$. MA failed to suppresess cholesterol elevation with statistical significance in high cholesterol rats (Table 2), despite a lowering tendancy. In contrast MA itselt was effective in lowering cholesterol in normal diet-fed rats. These results indirectly indicate that MA might have prevented the deterioration of vessel sensitivity-changing factors, presumably atherosclerotic culprits. For example, it is known that oxidation of low-density lipoprotein ${ }^{35)}$ or oxidation of cholesterol $^{36)}$ is directly related to atherosclerosis development. With regard to this line, it has been demonstrated that MA contains antioxidant flavonoids at $0.45 \%$ levels $^{37}$.

However, the current results can only provide speculative information regarding the principles specifically participate in such activities. The most probable explanation can be 
a. Norepinephrine

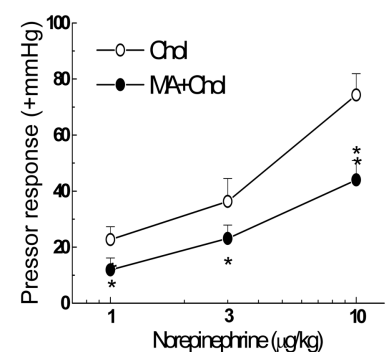

c. Angiotensin II

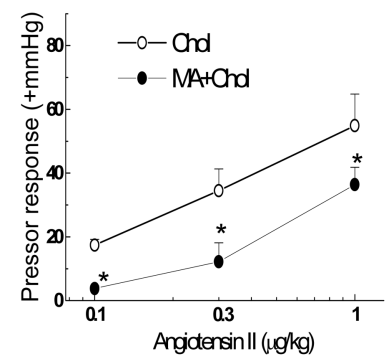

b. Phenyephrine

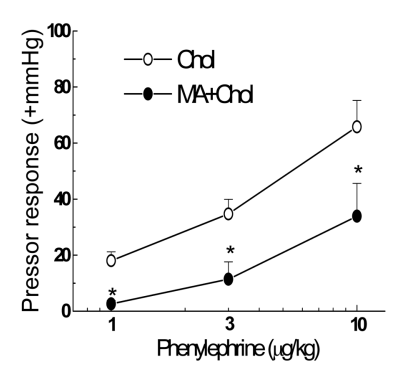

d. Vasopressin

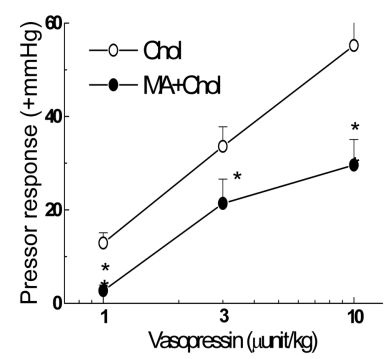

Fig. 2. Effects of M. alba leaf feeding on pressor responses elicited by different action mechanisms in pithed rats

$\mathrm{n}=5-7$

* Significant difference at $\mathrm{p}<0.05$ with Newman-Keul's t-test. Chol: high cholesterol diet; MA, M. alba diet

antioxidant effects of flavonol glycosides such as quercetin3-(6-molonylglucoside), rutin, isoquercitrin and astragalin ${ }^{10)}$. It is proposed that oxidized lipoprotein particles are incorporated into hypercholesterolemic rat arterial walls causing potentiated contraction to pressor agents ${ }^{22,23)}$. In summary, it was found in this study that MA leaves are beneficial in restoring normal blood vessel reactivity that are sensitized by high cholesterol diets. The effects might be linked to antioxidant activity of flavonols present in MA leaves at high concentrations. With regard to anti-atherosclerotic activity of MA, responsible substance(s) are not well identified. However, it is possible that antioxidant mechanisms could be involved for the beneficial effects because various bioactive substances have been identified from MA which antioxidative activity: quercetin 3-(6-malonylgucoside), rutin, quercetin, catechin, kaempferol and quercitrin. Epidemiological evidence suggest that dietary intake of antioxidant substances lower the development of atherosclerosis ${ }^{11}$.

The contrasting result between anesthtized and pithed rats justifies the use of pithed animals in assessing vascular sensitivity itself without participation of central involvement. Normally, blood pressure values are instantly regulated to maintain constant levels through central nervous systems. Hightened blood pressure levels are sensed by pressure sensors called "baroreceptors" present at the peripheral vessels, and then diminished sympathetic outflows reduce the

tone of resistance vessels $\mathrm{s}^{32}$. For a lowered blood pressure, the reverse mechanisms work. It seems that potentiated blood vessel reactivity to phenylephrine injection might have been obscured by to reflexly acting compensation of the cardiovascular function.

In summary, the reslts demonstrate that MA prevents the induction of blood vessel sensitivity in hypercholesterolemic condition.

\section{요 약}

동맥경화 상태에서는 혈관이 수축물질에 예민하게 반응 함으로써 혈압의 급격한 변화에 대한 회복능력이 저하한 다. 한편 뽕나무 잎에는 고지방식의 섭취로 인해 발생하 는 동맥경화증의 발달을 감소시킬 가능성이 있는 여러 물 질이 있다고 추정된다. 뽕나무 잎을 백서에 투여하면 고지 방식에 의해 유발된 혈관이 예민해지는 현상을 감소시킬 수 있는지 시험하기 위하여 고지방식 및 뽕나무잎을 8 주 간 투여하고 혈관수축 물질에 대한 혈압의 반응성을 시험 하였다. 순환기반사에 따른 혈압반응 감수성차이를 최소화 할 목적으로 동물의 중추신경계를 파괴(pithing)하고 시험 하였다. 고콜레스테롤을 함유한 식이를 공급한 백서에서 교감신경계 전기자극이나 norepinephrine, phenylephrine, angiotensin II 및 vasopressin 등의 투여로 유발된 혈압상 승반응이 증강되었으며, 사료에 뽕잎을 $2 \%$ 또는 $10 \%$ 첨 가하면 정상적인 혈압상승반응을 보여주었다. 교감신경계 를 파괴하지 않은 채 마취만 한 백서에서는 고콜레스테롤 에 의한 반응증강이나 뽕잎에 의한 변화를 관찰할 수 없 었다. 이 결과로 부터 뽕잎이 동맥경화에서 나타나는 혈 관반응성 변화를 방지하는 데 유용한 것으로 판단할 수 있을 것이다.

\section{References}

1. Srivastava S., Kapoor R., Thathola, A. and Srivastava, R.P.: Nutritional quality of leaves of some genotypes of mulberry (Morus alba). Int. J. Food Sci. Nutr. 57, 305-313 (2006).

2. Ercisli, S.: A short review of the fruit germplasm resources of turkey. Genetic Res. Crop Eval. 51, 419-435 (2004).

3. Arabshahi-Delouee, S. and Urooj, A.: Antioxidant properties of variuos solvent extract of mulberry (Morus indica L.) leaves. Food Chem. 102, 1233-1240 (2007).

4. Choi, E.M. and Hwang, J.K.: Effects of Morus alba leaf extract on the production of nitric oxide, prostaglandin E2 and cytokines in RAW2647 macrophages. Fitoterapia 76, 608-613 (2005).

5. Butt, M. S., Nazir, A., Sultan, M. T. and Schroën, K.: Morus alba L.: nature's functional tonic. Trends Food Sci. Technol. 19, 505-512 (2008).

6. Park, K.M., You, J.S., Lee, H.Y., Baek, N.I. and Hwang, J.K.: 
Kuwanon C: an antibacterial agent from the root bark of Morus alba against oral pathogens: J. Ethnopharmacol. 84, 181-185 (2003).

7. Sohn, H.Y., Son, K.H., Kwon, C.S., Kwon G.S. and Kang S.S.: Antimicrobial and cytotoxic activity of 18 prenuylated flavonoids isolated from medicinal plants: Morus alba L., Morus mongolica Schneider, Broussnetia papyrifera (L.) Vent, Sophora flavescens Ait and Echinosophora koreensis. Phytomedicine 11, 666-672 (2004).

8. Cui, L., Na, M.K, Oh, H., Bae, E.Y., Jeong, D.G. and Ryu, S.E.: Protein tyrosine phosphatase 1B inhibitors from Morus root bark. Bioorganic Med. Chem. Lett. 16, 1426-1429 (2006).

9. Kofujita, H., Yaguchi, M., Doi, N. and Suzuki, K.: A novel cytotoxic prenylated flavonoid from the root of Morus alba. J. Insect Biotechnol. Sericol. 73, 113-116 (2004).

10. Enkhmaa, B., Shiwaku, K., Katsube, T., Kitajima, K., Anuurad, E. and Yamasaki, M.: Mulberry (Morus alba L.) leaves and their major flavonol quercetin 3-(6-malonylglucoside) attenuate atheroscleosis lesion development in LDL receptor-deficient mice. J. Nutr. 135, $729-734$ (2005).

11. Katsube, T., Imawaka, N., Kawano, Y., Yamazaki, Y., Shiwaku, K. and Yamane, Y.: Antioxidant flavonol glycosides in mulberry (Morus alba L.) leaves isolated base on LDL antioxidant activity. Food Chem. Acta 97, 25-31 (2006).

12. Lee, J., Chae, K., Ha, J., Park, B.Y., Lee, H.S. and Jeong, S.: Regulation of obesity and lipid disorders by herbal extracts from Morus alba, Melissa officinalis and Artemisia capillaris in high-fat diet-induced obese mice. J. Ethnopharmacol. 115, 263-270 (2008).

13. Oku, T., Yamada, M., Nakamura, M., Sadamori, N. and Nakamura, S.: Inhibitory effects of extractives from leaves of Morus alba on human and rat small intestinal disaccharidase activity. Brit. J. Nutr. 95, 933-938 (2006).

14. Nam, S.Y., Yi, H.K., Lee, J.C., Kim, J.C., Song, C.H. and Park, J.W.: Cortex mori extract induces cancer apoptosis through inhibition of microtuble assembly. Arch. Pharmacol. Res. 25, 191-196 (2002).

15. Du, Z.Y. and Woodman, O.L.: The effect of hypercholesterolaemia and atherosclerosis on $\alpha$-adrenoceptor-mediated vasoconstriction in conscious rabbits and rabbit aorta. Eur. J. Pharmacol. 211, 149-156 (1992).

16. Rosendorff, C., Hoffman, J.I.E., Verrier, E.D., Rouleau, J. and Boerboom, L.E.: Cholesterol potentiates the coronary artery response to norepinephrine in anesthetized and conscious dogs. Cir. Res., 48, 320-329 (1981).

17. Heistad, D.D., Armstrong, M.L., Marcus, M.L., Piegors, D.J. and Mark, A.L.: Augumented responses to vasoconstrictor stimuli in hypercholesterolemic and atherosclerotic monkeys. Cir. Res. 54, 711-718 (1984).

18. Reeves, P.G., Nielson, F.H. and Fahey, G.C., Jr.: AIN-93 purified diets for laboratory rodents: final report of the American Institite of Nutrition ad hoc writing committee on the reformulation of the AIN-76A rodent diet. J. Nutr. 123, 19391951 (1993).

19. Rural Development Administration, Technology on Morus alba Utilization for Medicinal Substances, Research Report AOM 615-617, RDA (1996).

20. Shipley, R.E. and Tilden, J.H.: A pithed rats preparation suitable for assaying pressor substances. Proc. Soc. Exp. Biol. Med. 64, 453-455 (1947).

21. Gillespie, J.S., MaClaren, A. and Pollock, D.: A method of stimulating different segments of the autonomic outflow from the spinal column to various organs in the pithed cat and rat. Br. J. Pharmacol. 40, 257-267 (1970).

22. Grieve, D.J., Avella, M.A., Elliot, J. and Botham, K.M.: The interaction between oxidized chylomicron remnants and the aorta of rats fed a normocholesterolaemic or hypercholesterolaemic diets. J. Vasc. Res. 37, 265-275 (2000).

23. Maguire, J.J., Wiley, K.E., Kuc, R.E., Stoneman, V.E.A., Bennett, M.R. and Davenport, A.P.: Endothelin-mediated vasoconstriction in early atherosclerosis is markedly increased in $\mathrm{ApoE}^{-/-}$mouse but prevented by atorvastatin. Exp. Biol. Med. 231, 806-812 (2008).

24. Hoffman, B.B.: Catecholamines, sympathomimetic drugs, and adrenergic receptors. In Goodman and Gillman's The Pharmacological Basis of Therapeutics, 10th Ed. (Hardman, J.G., Limbird, L.E. and Gillman, A.G. eds.) McGraw Hill, New York, pp. 215-268 (2001).

25. Park, K.H.: Induction of cardiovascular anaphylaxis and basic pharmacological analysis of involved mediators in pithed rats. Biomolecules Ther. 16, 299-305 (2008).

26. Gillespie, J.S. and Muir, T.C.: A method of stimulating the complete sympathetic outflow from the spinal cord to blood vessels in the pithed rat. Br. J. Pharmacol. Chemother. 30, 7887 (1967).

27. Fozard, J.R., Mir, A.K and Middlemiss, D.N.: Cardiovascular response to 8-hydroxy-2-(di- $n$-propylamino) tetralin (8OH-DPAT) in the rat: site of action and pharmacological analysis. J. Cardiovasc. Pharmacol. 9, 328-347 (1987).

28. Alayan, H.H., Kennedy, B.P. and Ziegler, M.G.: The pressor effect of NO synthase inhibition correlates to pre-existing systolic BP in the rat. Autonom. Neurosci. 95, 32-36 (2002).

29. Grekin, R.J., Vollmer, A.P. and Sider, R.S.: Pressor effects of portal venous oleate infusion: a proposed mechanism for obesity hypertension. Hypertension 26, 193-138 (1995).

30. Paolisso, G., Manzella, D., Rizzo, M.R., Ragno, F., Barbiert, M., Varricchio, G. and Varricchio, M.: Elevated plasma fatty acid concentrations stimulate the cardiac autonomous nervous system in healthy subjects. Am. J. Clin. Nutr. 72, 723-730 (2000).

31. Santos, R.A.S., Campagnole-Santos, M.J. and Andrade, S.P.: Angiotensin-(1-7): an update. Regul. Peptides 91, 45-62 (2000).

32. Maybauer, M.O., Maybauer, D.M., Enkhbaatar, P. and Traber, D.L.: Physiology of vasopressin receptors. Best Practice Res. Clin. Anesthesiol. 22, 253-263 (2008).

33. Averill, D.B. and Diz, D.I.: Angiotensin peptides and baroreflex control of sympathetic outflow: pathways and mechanism of the medulla oblongata. Brain Res. Bull. 51, 119-128 (2000).

34. Mulvihill, E.E. and Huff, M.W.: Antiatherogenic properties of flavonoids: implication for cardiovascular health. Adv. 
Vasc. Biol. 22(Suppl. A), 17-21 (2010).

35. Heinecke, JW.: Oxidants and antioxidants in the pathogenesis of atherosclerosis: implication for the oxidized low density lipoprotein hypothesis. Athrosclerosis 141, 1-15 (1998).

36. Brown, A.J. and Jessup, W.: Oxysterols and atherosclerosis. Atherosclerosis 142, 1-28 (1999).
37. Lee,Y.J., Lee, W.J. and Choi, S.W.: Polyophenolic compounds and biological activity of four different parts of Morus alba and Cudrania tricuspidata. Collection of Research Papers in Natural Sciences, Catholic Uinversity of Daegu 8, 107-117 (2010). 